\title{
The Influence of Fair Value Measurement on Radical Financing of Irrational Managers Based on Fixed Effects Model and Fisher Permutation Test
}

\author{
Wei Wang $\mathbb{D}^{1},{ }^{1}$ Xiao-hui Qu $\mathbb{D}^{2,3}{ }^{2,3}$ Jian-Ju Du $\mathbb{D}^{4},{ }^{4}$ and Jia-Ming Zhu $\mathbb{D}^{5}$ \\ ${ }^{1}$ Institute of Financial and Accounting Studies, Xiamen University, Xiamen 361005, China \\ ${ }^{2}$ Center for Accouting Studies of Xiamen University, Xiamen 361005, China \\ ${ }^{3}$ School of Economics and Management, Harbin Institute of Technology, Shenzhen 518055, China \\ ${ }^{4}$ School of Accounting, Anhui University of Finance and Economics, Bengbu 233030, China \\ ${ }^{5}$ School of Statistics and Applied Mathematics, Anhui University of Finance and Economics, Bengbu 233030, China \\ Correspondence should be addressed to Jia-Ming Zhu; zhujm1973@163.com
}

Received 8 January 2021; Revised 21 January 2021; Accepted 10 February 2021; Published 22 February 2021

Academic Editor: M. Irfan Uddin

Copyright (c) 2021 Wei Wang et al. This is an open access article distributed under the Creative Commons Attribution License, which permits unrestricted use, distribution, and reproduction in any medium, provided the original work is properly cited.

\begin{abstract}
Adopting fair value measurement may bring more earnings fluctuations and induce irrational psychology and radical financing behavior of managers. Based on behavioral corporate governance theory, using the sample of Chinese A-share nonfinancial listed companies during 2007-2017, this paper empirically examines the regulatory effect of fair value measurement, that is, whether fair value measurement affects the company's financing decisions when managers have irrational psychological characteristics, i.e., overconfidence. The study found that overconfident managers of the company that have fair value measurement assets will be more aggressive for debt decisions, indicating that fair value measurement has a positively regulatory effect on overconfident managers.
\end{abstract}

\section{Introduction}

With the rapid development of the virtual economy, derivative financial instruments flood the international market and are frequently traded. China has gradually followed up and introduced fair value measurement standards in the "Accounting Standards for Business Enterprises" (2006). According to statistics from Guotaian, there were 1,329 nonfinancial listed companies using fair value measurement in 2007, and by 2017 there were 3,324 listed companies. Fair value measurement has been widely adopted by listed companies [1]. Changes in fair value may cause earnings fluctuations, and fair value accounting information has significant explanation for stock prices. The profit volatility measured by fair value is positively correlated with market volatility [2], and it is more significant in the volatility period of market than in the stable period [3]. Compared with historical cost measurement, fair value measurement has uncertainty, including market macroeconomic risks and estimation errors. The uncertainty of fair value measurement increases the probability of decision-makers' cognitive deviation, and the value relevance of fair value measurement is also stronger [4-6]. As the income statement item, fair value item, which is derived from the company's transactional financial assets, transactional financial liabilities, investment real estate measured by the fair value model, derivative financial instruments, and hedging business and other fair value changes that should be included in the current profit and loss, will obviously affect the company's predicted performance, significantly affect the company's forecast performance, which in turn will affect the company's stock price, and also affect the decision-making and judgment of managers. Therefore, earnings fluctuations caused by fair value measurement may lead to managerial decision-making bias. Behavioral corporate governance theory points out that company managers are sometimes irrational, and a common 
feature is overconfidence, which usually manifests as overestimation of returns and underestimation of risks. Overconfident managers may be more optimistic about the company when fair value changes positively, and treat unrealized gains as part of their own performance, and underestimate or ignore possible risks when fair value changes negatively. For companies that use fair value measurement, their overconfident managers may overestimate the company's operating status when making financing decisions and choose excessive debt financing. Does fair value measurement have a moderating effect, affecting the financing decisions of overconfident managers?

This article uses the data of the A-share nonfinancial listed companies in Shanghai and Shenzhen of China stock exchanges to test whether the moderating effect of fair value measurement will increase managers' irrational financing behavior. The fair value measurement is characterized by whether the fair value item in the income statement is zero, and managers' overconfidence is characterized by executive compensation, company performance forecasts, and executive characteristics. This study found that, for companies that use fair value measurement, their overconfident managers will choose more aggressive debt decisions. This article may contribute to the following: (1) expanding the application of behavioral corporate governance theory in fair value measurement. The research on fair value and managers' irrational behavior mainly includes financial assets and management overconfidence [7], fair value and investment decision $[8,9]$, etc. This article mainly studies the influence of fair value on the financing decisions of overconfident managers. It can enrich the relevant literature in the field of fair value measurement and behavioral corporate governance. (2) Since the use of the new accounting standards in 2007, some scholars have studied the influence of fair value on the relationship between earnings transparency and stock mispricing [10]. However, the perspective of this article provides a reference for the financing decision of companies that use fair value to measure assets.

\section{Theoretical Analysis and Research Hypothesis}

\subsection{Managers' Overconfidence, Debt Financing, and Fair Value Measurement}

2.1.1. Managers' Overconfidence and Debt Financing. In modern society, overconfidence of managers is a relatively common irrational psychology [11]. Scholars have done a lot of research on overconfidence, such as dividing high confidence and moderate confidence [12], and some studies on overconfidence of board secretary [13]. Since the cognitive bias of managers' overconfidence comes from excessive expectations of future returns, overconfident managers are usually risk-averse; they are optimistic about expected returns, and less consider risk of overdue payment and insolvency when facing liabilities. Therefore, their behavior in financing decision-making will conform to the theory of financing priority order; that is, compared to equity financing, they prefer debt financing [14-16]. Statistics on
China's A-share nonfinancial listed companies from 2007 to 2017 found that the asset-liability ratio reached an average of more than $40 \%$, with a maximum of $157 \%$, and showed an upward trend. Existing studies have found that the more overconfident managers are, the more debt financing the company has. Manager's overconfidence is significantly positively correlated with the asset-liability ratio, especially the short-term debt ratio, while the correlation between manager's overconfidence and the company's long-term debt is undetermined $[17,18]$. In general, managers' overconfidence is positively correlated with the asset-liability ratio. Overconfidence will lead managers to adopt debt financing more actively and prefer short-term debt. There is no conclusion on long-term debt.

\subsubsection{Fair Value Measurement and Irrational Behavior.} At present, financial reports in China have both historical cost measurement models and fair value measurement models, and their income composition is different. This is likely to cause company managers to pay more attention to the profits brought about by changes in fair value due to market fluctuations, and bias their perceptions of the company's profitability. How does the fluctuation of earnings caused by fair value measurement [19] affect the debt financing behavior of overconfident managers? Overconfident managers who carry out debt financing may have certain requirements in terms of business performance and need to whitewash their reports in order to obtain more funds or reduce the cost of debt. On the one hand, managers (regardless of whether they are overconfident) can use fair value to measure the uncertainty of valuation, and manipulate in the second or third level of valuation [20], such as the fair value of loans $[21,22]$ and the asset valuation of hedge funds [23], etc.; on the other hand, because accrual abnormal items are easier to be noticed by creditors, managers are often willing to carry out real earnings management to adjust profits. When fair value measurement does not consider valuation issues, its value is publicly quoted in the market, and there is little room for accrued earnings management. Overconfident managers will ignore the possibility of downward fluctuations in earnings measured by fair value and use them for real earnings management. Studies have found that the way to use fair value measurement for real earnings management is to adjust profits by increasing and reducing equity holdings, and disposing of financial assets. For example, listed companies will change the way they sell assets such as securities [24, 25] or change the sale time of trading financial assets and available-for-sale financial assets [26-28] to manipulate the company's earnings.

For overconfident managers, gains and losses from the changes in fair value will affect the company's performance and may affect the company's stock price when the performance is announced. Overconfident managers will regard the gains from the change in fair value as an optimistic signal when debt financing and ignore or underestimate the risk when the fair value changes are negative, thinking that the losses from changes in fair value are not actual confirmation 
and will not affect the company's actual operations, in order to maintain a high debt ratio. Therefore, the use of fair value measurement models may have a moderating effect, intensifying the tendency of overconfident managers to finance debt, leading to a higher asset-liability ratio. From this, we put forward the following hypothesis:

$H 1$ : under certain other conditions, fair value measurement has a positive moderating effect, causing overconfident managers to make more aggressive debt financing decisions and increase debt levels.

\section{Research Design}

\subsection{Variable Definition}

3.1.1. Dependent Variable. Assume debt level in hypothesis 1 with three indicators to measure, respectively, asset-liability ratio, the ratio of short-term debts, and long-term debt rates. Lev: the company's debt structure, namely, asset-liability ratio, measured by total liabilities/total assets. Llev: long-term debt ratio, measured by long-term debt/total assets. Slev: short-term debt ratio, measured by short-term debt/total assets.

3.1.2. Independent Variable. Con: the overconfident manager in hypothesis 1 . The academic community still has no unified conclusion on how to measure overconfidence. This article uses dummy variables to measure overconfidence. Comparing the top three executive salaries to the median of all executive salaries, if the current three executive salaries to all executive salaries are higher than the median, the managers are overconfident, which is counted as 1 , and if it is considered that managers are not overconfident, it is counted as $0[29,30]$. Afv: fair value measurement. It is a dummy variable. When the profit and loss of the fair value change in the income statement is not equal to 0 , it is taken as 1 , or it is taken as 0 . The fair value items in the income statement will bring a stronger market response [31] and have a higher value correlation because they are included in the net profit $[32,33]$.

3.1.3. Control Variables. Company size (L1Size): measured by the natural logarithm of total assets. When testing for multicollinearity, this paper found that the company scale value is too high and there may be multicollinearity. Therefore, the data with one period of lag is selected to exclude the influence of collinearity. Growth opportunity (Growth): the growth rate of total assets. Tangible assets (Ppe): net fixed assets/total assets; profitability (Prof): net profit/main business profit $[34,35]$.

3.2. Model Design. Use Yu Minggui et al. to build a Debt financing model:

$$
\begin{aligned}
\text { Lev }= & \partial_{0}+\partial_{1} \text { Con }+\partial_{2} \text { L1size }+\partial_{3} \text { Growth }+\partial_{4} \text { Prof } \\
& +\partial_{5} \text { Ppe }+\varepsilon .
\end{aligned}
$$

To verify hypothesis 1 , use the cross-product term:

$$
\begin{aligned}
\text { Lev }= & \partial_{0}+\partial_{1} \text { Con }+\partial_{2} \text { Afv }+\partial_{3} \text { Afv } \times \text { Con }+\partial_{4} \text { L1size } \\
& +\partial_{5} \text { Growth }+\partial_{6} \text { Prof }+\partial_{7} \text { Ppe }+\varepsilon
\end{aligned}
$$

Among them, the explained variable Lev includes assetliability ratio, long-term debt ratio, and short-term debt ratio; the explanatory variable is Con $\times \mathrm{Afv}$, which represents the incremental effect brought by fair value measurement. The coefficient of the cross-multiplication term is expected to be positive, indicating that fair value measurement has an incremental impact on the higher debt financing ratio caused by managers' overconfidence.

3.3. Data Source and Sample Selection. The data in this article mainly comes from the Chinese CSMAR database, and the performance forecast related data comes from the Wind database. The sample includes China's A-share nonfinancial listed companies from 2007 to 2017, and the industry classification adopts the 2012 industry classification of the China Securities Regulatory Commission. Since the manufacturing industry contains many categories, the manufacturing industry is subdivided. Due to the special financial reporting structure of the financial industry, excluding the financial industry, 21 categories will remain. Among them, (1) exclude listed companies in the financial and insurance industry; (2) exclude ST and $*$ ST companies; (3) exclude other sample companies with missing data. In order to eliminate the interference of outliers, the main continuous variables are processed by Winsorize up and down 1\%. Finally, 15393 observations were obtained. Mainly Stata15.0 was used for data processing and regression analysis.

\section{Empirical Test}

4.1. Descriptive Statistics. We used the CSMAR and Wind database to count the total, mean, standard deviation, minimum, median, and maximum values of all variables involved from 2007 to 2017, as shown in Table 1.

In Table 1, the average asset-liability ratio (Lev) is 0.43 . Some companies have a very high debt ratio, reaching $157 \%$, and some of them have a very small debt ratio. Overconfidence (Con), fair value measurement (Afv), and crossmultiplication term of the two $(\mathrm{Afv} \times \mathrm{Con})$ are all dummy variables, which are listed as 0 and 1 . On average, overconfidence (Con) and fair value measurement (Afv) account for about half of the total sample. Among other control variables, the minimum values of company growth (Growth) and company profitability (Prof) are negative, which are $-27 \%$ and $-626 \%$, respectively, and the average value is $24 \%$. Although some companies have poor performance, they are still increasing year by year, which is in line with the environment in which the economic situation has improved year by year after the financial crisis. The Prof is more obvious than the company's Growth, which reflects the differences between different companies; CEO duality (Dual). On average, 28\% of companies have the combination of chairman and general manager; Tangible assets (Ppe). Fixed assets account for an average of $22 \%$ of total assets. 
Table 1: Descriptive statistics.

\begin{tabular}{|c|c|c|c|c|c|c|}
\hline Variable & $N$ & Mean & $\mathrm{Sd}$ & Min & p50 & Max \\
\hline Lev/100\% & 15393 & 0.430 & 0.210 & 0.0100 & 0.420 & 1.570 \\
\hline Slev/100\% & 15393 & 0.110 & 0.110 & 0 & 0.090 & 0.850 \\
\hline Llev/100\% & 15393 & 0.170 & 0.170 & 0 & 0.120 & 0.740 \\
\hline Con & 15393 & 0.410 & 0.490 & 0 & 0 & 1 \\
\hline $\mathrm{Afv} \times$ Con & 15393 & 0.190 & 0.390 & 0 & 0 & 1 \\
\hline Afv & 15393 & 0.470 & 0.500 & 0 & 0 & 1 \\
\hline L1size/yuan & 15393 & 21.930 & 1.200 & 19.630 & 21.760 & 26.950 \\
\hline Growth $100 \%$ & 15393 & 0.240 & 0.470 & -0.270 & 0.120 & 3.300 \\
\hline Dual & 15393 & 0.280 & 0.450 & 0 & 0 & 1 \\
\hline Prof/100\% & 15393 & 0.240 & 0.960 & -6.260 & 0.310 & 4.720 \\
\hline Ppe/100\% & 15393 & 0.220 & 0.160 & 0 & 0.190 & 0.720 \\
\hline
\end{tabular}

According to the standard deviation, it can be seen from the minimum that the overall distribution is around $20 \%$, and it is very rare for the maximum to reach $72 \%$.

4.2. Pearson Coefficient Test. In order to observe the correlation between the variables, the Pearson coefficient test was performed on all variables, and the results are shown in Table 2.

In the Pearson coefficient test in Table 2, it can be seen that the coefficients of manager overconfidence (Con) and the cross-multiplication term $(\mathrm{Afv} \times \mathrm{Con})$ reach 0.59 , which may have multicollinearity. To exclude this part of the impact, this article did a VIF factor analysis on the corresponding variables, and the VIF results in Table 3 did not exceed 3, indicating that there is no multicollinearity between the variables.

\subsection{Regression Results of Fair Value, Managerial Overconfi-} dence, and Debt Ratio. First, the Hausman test is performed. Since the $P$ value of the test result is negative, fixed-effects model regression is selected. The model is controlled by industry and year, and the results are tested for heteroscedasticity and autocorrelation. Because there is a certain degree of heteroscedasticity, this paper uses robust standard errors to eliminate heteroscedasticity to ensure the robustness of the model.

According to column (1) of Table 4, there is a significant positive correlation between the cross-multiplication term $(\mathrm{Afv} \times \mathrm{Con})$ and the asset-liability ratio (Lev) at the level of $1 \%$. Assumption 1 in this article is proved; that is, overconfident managers of companies that use fair value measurement will choose a more aggressive liability structure.

From columns (2) and (3), it can be seen that there is no correlation between the fair value measurement and the manager's overconfidence cross-multiplication term $(\mathrm{Afv} \times \mathrm{Con})$, short-term debt ratio (Slev), and long-term debt ratio (Llev). In other words, fair value measurement has nothing to do with whether overconfident managers choose more aggressive shortterm liabilities and long-term liabilities. In order to ensure the accuracy of the results, this article did a robustness test.

\section{Further Research}

5.1. The Influence of Internal Control on the Adjustment of Fair Value Measurement. The market is usually semi-strong or weakly effective. At this time, information users can obtain publicly available information from the capital market, such as financial reports and analyst ratings, but the company's internal operations are relatively hidden. Due to information asymmetry, overconfident managers may use fair value measurement for real earnings management to adjust profits in order to obtain lower debt financing costs. Effective internal control can improve the company's control environment, thereby promoting more rational corporate behavior, and curbing financial fraud and earnings manipulation, to some extent. Some scholars have studied relational transactions and found that good internal control can help suppress the positive real earnings management induced by supplier relational transactions [36].

This article uses the internal control IC index in the CCER database to measure the company's internal control system; the descriptive statistics are shown in Table 5 . Among them, the value higher than the average value 661.6 is $\mathrm{MIC}=1$, and the value lower than the average value is MIC $=0$. Grouped regression results are as shown in Table 6 . The coefficients of Afv $\times$ Con in columns (1) and (2) are 0.0296 and 0.0089 , respectively, and the former is significantly positive at the $5 \%$ level, and the empirical $P$ value between groups is significant, which is 0.092 . The test results show that, in companies with a low internal control index, the adjustment effect of fair value measurement is more significant, which obviously induces overconfident managers to carry out debt financing and raises the asset-liability ratio. This may be due to the fact that fair value measurement is more valuable and relevant in an environment with asymmetric information [37]. In columns (3) to (6), the short-term debt ratio and the long-term debt ratio are tested, respectively, but the grouping results are not significant.

5.2. The Impact of Environmental Uncertainty on the Moderating Effect of Fair Value Measurement. The Internet has brought many variables, and many scholars in different fields have conducted research $[38,39]$. The transportation network brought about by the popularization of high-speed rail and the trading network brought about by the prosperity of the market all have an impact. When the third-level measurement is not considered (without public quotation), the surplus fluctuations of financial assets measured by fair value are usually quoted on the open market. It is difficult for managers to obtain private profits by investing in financial 
TABLE 2: Pearson coefficient test.

\begin{tabular}{lccccccccc}
\hline Variable & Lev & Con & $\mathrm{Afv} \times$ Con & $\mathrm{Afv}$ & L1size & Dual & Prof & Growth & Ppe \\
\hline Lev & 1 & - & - & - & - & - & - & - & - \\
Con & $-0.097^{* * *}$ & 1 & - & - & - & - & - & - & - \\
Afv $\times$ Con & $-0.013^{*}$ & $0.599^{* * *}$ & 1 & - & - & - & - & - & - \\
Afv & $0.062^{* * *}$ & -0.003 & $0.514^{* * *}$ & 1 & - & - & - & - & - \\
L1size & $0.161^{* * *}$ & $-0.043^{* * *}$ & $0.043^{* * *}$ & $0.154^{* * *}$ & 1 & - & - & - & - \\
Dual & $-0.154^{* * *}$ & $0.154^{* * *}$ & $0.075^{* * *}$ & -0.003 & $-0.108^{* * *}$ & 1 & - & - & - \\
Prof & $-0.116^{* * *}$ & $0.020^{* * *}$ & $0.021^{* * *}$ & 0.006 & $-0.021^{* * *}$ & -0.005 & 1 & - & - \\
Growth & -0.002 & 0.009 & $0.021^{* * *}$ & $0.016^{* *}$ & $-0.064^{* * *}$ & $0.035^{* * *}$ & $0.106^{* * *}$ & 1 & - \\
Ppe & $0.105^{* * *}$ & $-0.050^{* * *}$ & $-0.067^{* * *}$ & $-0.081^{* * *}$ & $0.063^{* * *}$ & $-0.089^{* * *}$ & $-0.073^{* * *}$ & $-0.168^{* * *}$ & 1 \\
\hline
\end{tabular}

Symbols ${ }^{* * *},{ }^{* *}$, and ${ }^{*}$ represent significance levels of $1 \%, 5 \%$, and $10 \%$, respectively.

TABLE 3: Variance inflation factor (VIF) test.

\begin{tabular}{lcccccccrr}
\hline Variable & Lev & Con & Afv $\times$ Con & Afv & L1size & Dual & Prof & Growth & Ppe \\
\hline VIF & 1.36 & 1.96 & 2.60 & 2.38 & 1.11 & 1.08 & 1.03 & 1.07 & 1.44 \\
\hline
\end{tabular}

TABLE 4: Fixed effect regression of fair value, manager overconfidence, and debt ratio.

\begin{tabular}{lccc}
\hline Regression model & $(1) \mathrm{Lev}$ & $(2)$ Slev & (3) Llev \\
\hline \multirow{2}{*}{ Con } & $-0.0451^{* * *}$ & $-0.0139^{* *}$ & -0.00618 \\
& $(0.000)$ & $(0.035)$ & $(0.418)$ \\
Afv $\times$ Con & $0.0181^{* * *}$ & 0.00410 & -0.00176 \\
& $(0.004)$ & $(0.339)$ & $(0.559)$ \\
Afv & $0.0462^{* * *}$ & $0.0207^{* * *}$ & $0.0184^{* * *}$ \\
& $(0.005)$ & $(0.003)$ & $(0.001)$ \\
L1size & $0.0186^{* * *}$ & 0.00148 & $0.0108^{* * *}$ \\
& $(0.002)$ & $(0.372)$ & $(0.004)$ \\
Growth & $0.0166^{* *}$ & 0.00355 & $0.0238^{* * *}$ \\
& $(0.032)$ & $(0.205)$ & $(0.000)$ \\
Prof & $0.214^{* * *}$ & $-0.0129^{* * *}$ & 0.00184 \\
& $(0.000)$ & $(0.000)$ & $(0.555)$ \\
Ppe & $-0.0451^{* * *}$ & $0.140^{* * *}$ & $0.169^{* * *}$ \\
& $(0.000)$ & $(0.001)$ & $(0.005)$ \\
\hline Year/Ind & Yes & Yes & Yes \\
\hline$N$ & 14187 & 14187 & 14187 \\
Adj. $R^{2}$ & 0.241 & 0.122 & 0.169 \\
\hline
\end{tabular}

Symbols ${ }^{* * *},{ }^{* *}$, and ${ }^{*}$ represent significance levels of $1 \%, 5 \%$, and $10 \%$, respectively.

TABLE 5: Descriptive statistics of IC.

\begin{tabular}{lccccc}
\hline Variable & Mean & Sd & Min & p50 & Max \\
\hline IC & 661.6 & 116.3 & 0 & 678.3 & 993.2 \\
\hline
\end{tabular}

The data IC comes from the CCER database, including the period 2007 to 2017.

assets, and most of them are measured by fair value to carry out real earnings management. Companies with high environmental uncertainty usually reduce the true earnings management based on sales manipulation and productive manipulation [40]. Therefore, it is expected that the adjustment effect of fair value measurement will decrease under the circumstances of high environmental uncertainty. EU refers to environmental uncertainty, which is measured by company performance fluctuations with reference to Ghosh and Olsen [41]. Calculate the standard deviation of the company's abnormal sales income in the past 5 years, and divide it by the average of the sales income in the past 5 years to get the environmental uncertainty without industry adjustment. The company's unadjusted environmental uncertainty divided by the industrial environmental uncertainty is the company's environmental uncertainty after industry adjustment. The descriptive statistics of EU are shown in Table 7. MEU is the mean value of EU; $M E U=1$ indicates it is higher than the mean value, and $M E U=0$ indicates it is lower than the mean value.

As shown in Table 8, the coefficients of Afv $\times$ Con in columns (1) and (2) are 0.023 and 0.005 , respectively, and the former is significantly positive at the $1 \%$ level, and the empirical $P$ value between groups is significant, which is 0.061 . It shows that, in companies with low environmental uncertainty, the adjustment effect of fair value measurement is more significant, which obviously affects the overconfident management to carry out debt financing and increases the asset-liability ratio. In columns (3) to (6), the short-term debt ratio and the long-term debt ratio are tested separately, but the grouping results are not significant. The adjustment effect of fair value measurement is affected by the environment, and only when the economic environment is good or relatively stable will it significantly affect the management's decision-making.

\section{Robustness Test}

6.1. Using Earnings Forecasts and Executive Characteristics to Measure Overconfidence. Since there are many ways to measure overconfidence, this article [42] refers to the method of Lin et al. and adopts the second measurement method to test the robustness of the overconfidence indicator. Taking all nonfinancial listed companies that have released optimistic performance forecasts (including turnaround, continued profitability, slight increase, and preincreasing) in the third quarter as a sample, if the actual 
TABLE 6: The influence of internal control on the adjustment of fair value measurement.

\begin{tabular}{|c|c|c|c|c|c|c|}
\hline $\begin{array}{l}\text { Regression model } \\
\text { Variable }\end{array}$ & $\begin{array}{l}\text { (1) Lev } \\
\text { MIC }=0\end{array}$ & $\begin{array}{l}\text { (2) Lev } \\
\text { MIC }=1\end{array}$ & $\begin{array}{l}\text { (3) Slev } \\
\text { MIC }=0\end{array}$ & $\begin{array}{l}\text { (4) Slev } \\
\text { MIC }=1\end{array}$ & $\begin{array}{l}\text { (5) Llev } \\
\text { MIC }=0\end{array}$ & $\begin{array}{l}\text { (6) Llev } \\
\text { MIC = } 1\end{array}$ \\
\hline Con & $\begin{array}{c}-0.0472^{* * *} \\
(0.000)\end{array}$ & $\begin{array}{c}-0.0341^{* * *} \\
(0.000)\end{array}$ & $\begin{array}{c}-0.0242^{* * *} \\
(0.000)\end{array}$ & $\begin{array}{c}-0.0110^{* * *} \\
(0.000)\end{array}$ & $\begin{array}{c}-0.000415 \\
(0.952)\end{array}$ & $\begin{array}{c}-0.00572 \\
(0.222)\end{array}$ \\
\hline $\mathrm{Afv} \times \mathrm{Con}$ & $\begin{array}{c}0.0296^{* *} \\
(0.022)\end{array}$ & $\begin{array}{c}0.00894 \\
(0.241)\end{array}$ & $\begin{array}{l}0.00814 \\
(0.277)\end{array}$ & $\begin{array}{c}0.00403 \\
(0.343)\end{array}$ & $\begin{array}{c}0.00359 \\
(0.741)\end{array}$ & $\begin{array}{c}-0.00475 \\
(0.472)\end{array}$ \\
\hline Afv & $\begin{array}{c}0.0295^{* * *} \\
(0.002)\end{array}$ & $\begin{array}{c}0.0608^{* * * *} \\
(0.000)\end{array}$ & $\begin{array}{c}0.0166^{* * *} \\
(0.003)\end{array}$ & $\begin{array}{c}0.0236^{* * *} \\
(0.000)\end{array}$ & $\begin{array}{l}0.0129 \\
(0.106)\end{array}$ & $\begin{array}{c}0.0194^{* * *} \\
(0.000)\end{array}$ \\
\hline L1size & $\begin{array}{c}0.0206^{* * *} \\
(0.000)\end{array}$ & $\begin{array}{c}0.0175^{* * *} \\
(0.000)\end{array}$ & $\begin{array}{c}0.00242 \\
(0.123)\end{array}$ & $\begin{array}{c}0.00172^{*} \\
(0.054)\end{array}$ & $\begin{array}{l}0.00915^{* * *} \\
(0.000)\end{array}$ & $\begin{array}{c}0.00850^{* * *} \\
(0.000)\end{array}$ \\
\hline Dual & $\begin{array}{c}-0.0251^{* * *} \\
(0.001)\end{array}$ & $\begin{array}{c}-0.0379^{* * *} \\
(0.000)\end{array}$ & $\begin{array}{l}0.00242 \\
(0.565)\end{array}$ & $\begin{array}{c}-0.0000897 \\
(0.971)\end{array}$ & $\begin{array}{c}-0.0260^{* * *} \\
(0.000)\end{array}$ & $\begin{array}{c}-0.0178^{* * *} \\
(0.000)\end{array}$ \\
\hline Prof & $\begin{array}{c}-0.0189^{* * *} \\
(0.000)\end{array}$ & $\begin{array}{c}-0.0564^{* * *} \\
(0.000)\end{array}$ & $\begin{array}{c}-0.00791^{* * *} \\
(0.000)\end{array}$ & $\begin{array}{c}-0.0230^{* * *} \\
(0.000)\end{array}$ & $\begin{array}{c}-0.00180 \\
(0.409)\end{array}$ & $\begin{array}{c}0.0148^{* * *} \\
(0.000)\end{array}$ \\
\hline Growth & $\begin{array}{c}0.0232^{* * *} \\
(0.003)\end{array}$ & $\begin{array}{c}0.0275^{* * *} \\
(0.000)\end{array}$ & $\begin{array}{c}0.00285 \\
(0.521)\end{array}$ & $\begin{array}{c}0.00521^{* *} \\
(0.026)\end{array}$ & $\begin{array}{c}0.0275^{* * *} \\
(0.000)\end{array}$ & $\begin{array}{c}0.0263^{* * *} \\
(0.000)\end{array}$ \\
\hline Ppe & $\begin{array}{c}0.189^{* * * *} \\
(0.000)\end{array}$ & $\begin{array}{c}0.149^{* * * *} \\
(0.000)\end{array}$ & $\begin{array}{c}0.151^{* * * *} \\
(0.000)\end{array}$ & $\begin{array}{c}0.129^{* * *} \\
(0.000)\end{array}$ & $\begin{array}{c}0.131^{* * *} \\
(0.000)\end{array}$ & $\begin{array}{c}0.210^{* * * *} \\
(0.000)\end{array}$ \\
\hline $\begin{array}{l}\text { Year/Ind } \\
\text { Empirical } P \text { value }\end{array}$ & \multicolumn{2}{|c|}{0.092} & Yes & Yes & \multicolumn{2}{|c|}{0.223} \\
\hline $\begin{array}{l}N \\
\text { Adj. } R^{2}\end{array}$ & $\begin{array}{l}3803 \\
0.218\end{array}$ & $\begin{array}{l}8629 \\
0.282\end{array}$ & $\begin{array}{l}3803 \\
0.148\end{array}$ & $\begin{array}{l}8629 \\
0.125\end{array}$ & $\begin{array}{l}3803 \\
0.154\end{array}$ & $\begin{array}{l}8629 \\
0.195\end{array}$ \\
\hline
\end{tabular}

Symbols ${ }^{* * *},{ }^{* *}$, and ${ }^{*}$ represent significance levels of $1 \%, 5 \%$, and $10 \%$, respectively. The empirical $P$ value is the result of 1000 repeated sampling of Fisher permutation test. When $P<0.1$, the difference between groups is significant, the same below.

Table 7: Descriptive statistics of EU.

\begin{tabular}{lccccc}
\hline Variable & Mean & Sd & Min & p50 & Max \\
\hline EU & 1.33 & 1.35 & 0.02 & 0.97 & 19.69 \\
\hline
\end{tabular}

The original EU data comes from the CSMAR database, including the period 2007 to 2017.

TABLE 8: The influence of environmental uncertainty on the adjustment of fair value measurement.

\begin{tabular}{|c|c|c|c|c|c|c|}
\hline $\begin{array}{l}\text { Regression model } \\
\text { Variable }\end{array}$ & $\begin{array}{l}\text { (1) Lev } \\
\mathrm{MEU}=0\end{array}$ & $\begin{array}{l}\text { (2) Lev } \\
\mathrm{MEU}=1\end{array}$ & $\begin{array}{l}\text { (3) Slev } \\
\mathrm{MEU}=0\end{array}$ & $\begin{array}{l}\text { (4) Slev } \\
\mathrm{MEU}=1\end{array}$ & $\begin{array}{l}\text { (5) Llev } \\
\mathrm{MEU}=0\end{array}$ & $\begin{array}{l}\text { (6) Llev } \\
\mathrm{MEU}=1\end{array}$ \\
\hline Con & $\begin{array}{c}-0.0512^{* * *} \\
(0.000)\end{array}$ & $\begin{array}{c}-0.0321^{* * *} \\
(0.000)\end{array}$ & $\begin{array}{c}-0.0149^{* * *} \\
(0.000)\end{array}$ & $\begin{array}{l}-0.0140^{\text {*** }} \\
(0.000)\end{array}$ & $\begin{array}{c}-0.0185^{* * *} \\
(0.001)\end{array}$ & $\begin{array}{l}0.00384 \\
(0.464)\end{array}$ \\
\hline $\mathrm{Afv} \times \mathrm{Con}$ & $\begin{array}{c}0.0235^{* * *} \\
(0.008)\end{array}$ & $\begin{array}{c}0.00500 \\
(0.610)\end{array}$ & $\begin{array}{c}0.00820 \\
(0.116)\end{array}$ & $\begin{array}{c}0.00284 \\
(0.600)\end{array}$ & $\begin{array}{c}0.00647 \\
(0.413)\end{array}$ & $\begin{array}{l}-0.00774 \\
(0.354)\end{array}$ \\
\hline Afv & $\begin{array}{c}0.0238^{* * *} \\
(0.000)\end{array}$ & $\begin{array}{c}0.0731^{* * *} \\
(0.000)\end{array}$ & $\begin{array}{l}0.0104^{* * *} \\
\quad(0.008)\end{array}$ & $\begin{array}{c}0.0306^{* * *} \\
\quad(0.000)\end{array}$ & $\begin{array}{r}0.0122^{* *} \\
(0.027)\end{array}$ & $\begin{array}{c}0.0231^{* * *} \\
(0.000)\end{array}$ \\
\hline L1 size & $\begin{array}{l}0.00682^{* * *} \\
\quad(0.000)\end{array}$ & $\begin{array}{c}0.0284^{* * * *} \\
(0.000)\end{array}$ & $\begin{array}{r}-0.00120 \\
(0.258)\end{array}$ & $\begin{array}{c}0.00458^{* * *} \\
(0.000)\end{array}$ & $\begin{array}{c}0.00594^{* * *} \\
(0.000)\end{array}$ & $\begin{array}{c}0.0127^{* * *} \\
(0.000)\end{array}$ \\
\hline Prof & $\begin{array}{c}-0.0370^{* * *} \\
(0.000)\end{array}$ & $\begin{array}{c}-0.0241^{* * *} \\
(0.000)\end{array}$ & $\begin{array}{c}-0.0180^{* * *} \\
(0.000)\end{array}$ & $\begin{array}{c}-0.0114^{* * *} \\
(0.000)\end{array}$ & $\begin{array}{c}0.00269 \\
(0.451)\end{array}$ & $\begin{array}{c}0.00419 \\
(0.156)\end{array}$ \\
\hline Growth & $\begin{array}{l}0.0328^{* * *} \\
\quad(0.001)\end{array}$ & $\begin{array}{c}0.0278^{* * *} \\
(0.000)\end{array}$ & $\begin{array}{c}-0.000188 \\
(0.967)\end{array}$ & $\begin{array}{l}0.00284 \\
(0.195)\end{array}$ & $\begin{array}{c}0.0628^{* * *} \\
(0.000)\end{array}$ & $\begin{array}{c}0.0191^{* * *} \\
(0.000)\end{array}$ \\
\hline Ppe & $\begin{array}{c}0.0928^{* * *} \\
(0.000)\end{array}$ & $\begin{array}{r}0.228^{* * *} \\
(0.000)\end{array}$ & $\begin{array}{r}0.135^{* * * *} \\
(0.000)\end{array}$ & $\begin{array}{r}0.137^{* * *} \\
(0.000)\end{array}$ & $\begin{array}{r}0.165^{* * *} \\
(0.000)\end{array}$ & $\begin{array}{r}0.219^{* * *} \\
(0.000)\end{array}$ \\
\hline $\begin{array}{l}\text { Year/Ind } \\
\text { Empirical } P \text { value }\end{array}$ & Yes & Yes & Yes & 0.106 & 0.093 & Yes \\
\hline$N$ & 6619 & 5813 & 6619 & 5813 & 6619 & 5813 \\
\hline Adj. $R^{2}$ & 0.243 & 0.276 & 0.122 & 0.144 & 0.184 & 0.175 \\
\hline
\end{tabular}

Symbols ${ }^{* * *},{ }^{* *}$, and ${ }^{*}$ represent significance levels of $1 \%, 5 \%$, and $10 \%$, respectively. 
TABle 9: Descriptive statistics of Con2 and Con3.

\begin{tabular}{lcccrr}
\hline Variable & Mean & Sd & Min & p50 & Max \\
\hline Con2 & 0.02 & 0.14 & 0.00 & 0.00 & 1.00 \\
Con3 & 0.34 & 0.47 & 0.00 & 0.00 & 1.00 \\
\hline
\end{tabular}

The original data comes from the CSMAR database, from 2007 to 2017.

TABLE 10: Tests on earnings forecasts and executive characteristics measuring overconfidence.

\begin{tabular}{|c|c|c|c|}
\hline $\begin{array}{l}\text { Regression model } \\
\text { Variable }\end{array}$ & $\begin{array}{l}(1) \\
\text { Lev }\end{array}$ & $\begin{array}{c}(2) \\
\text { Slev }\end{array}$ & $\begin{array}{l}(3) \\
\text { Llev }\end{array}$ \\
\hline Con2 & $\begin{array}{l}0.0206 \\
(0.320)\end{array}$ & $\begin{array}{c}0.0221^{* *} \\
(0.046)\end{array}$ & $\begin{array}{l}0.0162 \\
(0.391)\end{array}$ \\
\hline $\mathrm{Afv} \times \mathrm{Con} 2$ & $\begin{array}{l}0.0546^{*} \\
(0.090)\end{array}$ & $\begin{array}{l}0.0214 \\
(0.264)\end{array}$ & $\begin{array}{c}-0.0528^{* *} \\
(0.026)\end{array}$ \\
\hline Afv & $\begin{array}{c}0.0546^{* * *} \\
(0.000)\end{array}$ & $\begin{array}{c}0.0226^{* * *} \\
(0.000)\end{array}$ & $\begin{array}{c}0.0183^{* * *} \\
(0.000)\end{array}$ \\
\hline L1size & $\begin{array}{c}0.0189^{* * *} \\
(0.000)\end{array}$ & $\begin{array}{c}0.00168^{* *} \\
(0.028)\end{array}$ & $\begin{array}{c}0.0109^{* * *} \\
(0.000)\end{array}$ \\
\hline Growth & $\begin{array}{c}0.0217^{* * * *} \\
(0.000)\end{array}$ & $\begin{array}{c}0.00363^{* *} \\
(0.038)\end{array}$ & $\begin{array}{c}0.0238^{* * *} \\
(0.000)\end{array}$ \\
\hline Prof & $\begin{array}{c}-0.0269^{* * *} \\
(0.000)\end{array}$ & $\begin{array}{c}-0.0131^{* * *} \\
(0.000)\end{array}$ & $\begin{array}{c}0.00182 \\
(0.354)\end{array}$ \\
\hline Ppe & $\begin{array}{c}0.203^{* * *} \\
(0.000)\end{array}$ & $\begin{array}{c}0.141^{* * *} \\
(0.000)\end{array}$ & $\begin{array}{c}0.170^{* * *} \\
(0.000)\end{array}$ \\
\hline Year/Ind & Yes & Yes & Yes \\
\hline $\begin{array}{l}N \\
\text { Adj. } R^{2}\end{array}$ & $\begin{array}{l}14187 \\
0.234 \\
\end{array}$ & $\begin{array}{l}14187 \\
0.120 \\
\end{array}$ & $\begin{array}{l}14187 \\
0.169 \\
\end{array}$ \\
\hline Con3 & $\begin{array}{c}-0.00656 \\
(0.729)\end{array}$ & $\begin{array}{c}-0.00336 \\
(0.756)\end{array}$ & $\begin{array}{l}0.0226 \\
(0.161)\end{array}$ \\
\hline $\mathrm{Afv} \times \mathrm{Con} 3$ & $\begin{array}{c}0.0615^{* *} \\
(0.013)\end{array}$ & $\begin{array}{l}0.0146 \\
(0.324)\end{array}$ & $\begin{array}{c}-0.0166 \\
(0.439)\end{array}$ \\
\hline Afv & $\begin{array}{c}0.0490^{* * * *} \\
(0.004)\end{array}$ & $\begin{array}{c}0.0276^{* * *} \\
(0.007)\end{array}$ & $\begin{array}{l}0.0139 \\
(0.272)\end{array}$ \\
\hline L1size & $\begin{array}{c}0.00532 \\
(0.288)\end{array}$ & $\begin{array}{c}-0.00440 \\
(0.149)\end{array}$ & $\begin{array}{c}0.0129^{* * *} \\
(0.002)\end{array}$ \\
\hline Growth & $\begin{array}{c}0.0301^{* *} \\
(0.018)\end{array}$ & $\begin{array}{c}0.00632 \\
(0.249)\end{array}$ & $\begin{array}{c}0.0229^{* * *} \\
(0.006)\end{array}$ \\
\hline Prof & $\begin{array}{c}-0.0364^{* * *} \\
(0.000)\end{array}$ & $\begin{array}{c}-0.00897^{* * *} \\
(0.006)\end{array}$ & $\begin{array}{c}-0.0104^{* *} \\
(0.021)\end{array}$ \\
\hline Ppe & $\begin{array}{c}0.253^{* * *} \\
(0.000)\end{array}$ & $\begin{array}{c}0.168^{* * * *} \\
(0.000)\end{array}$ & $\begin{array}{c}0.177^{* * *} \\
(0.000)\end{array}$ \\
\hline Year/Ind & Yes & Yes & Yes \\
\hline $\begin{array}{l}N \\
\text { Adj. } R^{2}\end{array}$ & $\begin{array}{l}1105 \\
0.230\end{array}$ & $\begin{array}{l}1105 \\
0.148\end{array}$ & $\begin{array}{l}1105 \\
0.226\end{array}$ \\
\hline
\end{tabular}

Symbols ${ }^{* * *},{ }^{* *}$, and ${ }^{*}$ represent significance levels of $1 \%, 5 \%$, and $10 \%$, respectively.

performance in 2007-2017 does not reach the expected level (that is, the performance forecast changes face), then define its managers as overconfident managers (Con2). In order to make the data more rigorous, the data in which the actual net profit is negative for two or more times in the sample and the performance forecast is positive is used as a measure of manager's overconfidence. In addition, taking the research of Jiang Wei [43] and Yu Minggui [44] as a reference, a third measurement method is adopted, which is to characterize overconfidence according to the characteristics of company managers (Con3). The descriptive statistics of the two kinds of overconfidence data are shown in Table 9 and the regression results are shown in Table 10. The asset-liability ratio and short-term debt ratio are consistent with the previous article. The long-term debt ratio is still unstable and in line with expectations.

\section{Conclusion}

Fair value related research based on behavioral corporate governance theory usually focuses on the relationship between irrational investors and fair value measurement. This paper uses the influence of fair value measurement on the current profit and loss to investigate whether the adjustment effect of fair value measurement has an impact on the radical financing behavior of irrational managers. 
This article selects executive compensation, whether the performance forecast has repeatedly changed faces, and the characteristics of executives as measures of manager's overconfidence. It is found that fair value measurement will affect overconfident managers making more aggressive debt financing decisions and maintaining a higher asset-liability ratio, but it has nothing to do with the more aggressive shortterm debt ratio, and the outcome with the long-term debt ratio is uncertain. Further research found that, in conditions of low environmental uncertainty and poor internal control quality, the moderating effect of fair value measurement is more likely to affect the debt financing behavior of overconfident managers. These research findings reveal the characteristics of the overconfident manager's financing decision-making behavior of companies that use fair value measurement, thereby expanding the relevant theories of corporate governance, and providing references for seeking relevant paths to optimize corporate governance from the perspectives of internal governance and external supervision.

\section{Data Availability}

The data used to support the findings of this study are included within the article.

\section{Conflicts of Interest}

The authors declare that there are no conflicts of interest regarding the publication of this paper.

\section{Acknowledgments}

This study was funded by Anhui Provincial Department of Education Quality Engineering Project (Planning Textbook), Economic Benefit Audit (No. 2017ghjc119), Anhui Provincial Department of Education Quality Engineering Project (MOOC), Audit (No. 2018mooc055), and Major Project of the Key Research Base of Humanities and Social Sciences of the Ministry of Education "Accounting Measurement Model, Report Model and Enterprise Comprehensive Report” (16JJD790035).

\section{References}

[1] L. Cai, J. W. Tang, and C. Cai, "Fair value measurement, earnings management, and auditor coping strategies," Accounting Research, vol. 11, pp. 85-91, 2018.

[2] L. D. Hodder, P. E. Hopkins, and J. M. Wahlen, "Risk-relevance of fair-value income measures for commercial banks," The Accounting Review, vol. 81, no. 2, pp. 337-375, 2006.

[3] Y. M. Hu and Y. J. Liu, "Fair value accounting and market volatility," Accounting Research, vol. 6, pp. 12-18, 2012.

[4] M. E. Barth, W. H. Beaver, and W. R. Landsman, "Relative valuation roles of equity book value and net income as a function of financial health," Journal of Accounting and Economics, vol. 25, no. 1, pp. 1-34, 1998.

[5] K. Nelson, "Fair value accounting for commercial banks an empirical analysis of SFAS No.107," The Accounting Review, vol. 71, no. 2, pp. 161-182, 1996.
[6] E. A. Eccher, K. Ramesh, and S. R. Thiagarajan, "Fair value disclosures by bank holding companies," Journal of Accounting and Economics, vol. 22, no. 1-3, pp. 79-117, 1996.

[7] X. Y. Zeng and J. C. Xu, "Fair value measurement, financial investment behavior and company capital structure," Journal of Financial Research, vol. 3, pp. 181-193, 2013.

[8] H. G. Shi, S. X. Li, and Y. L. Xiong, “"Fair value accounting and investment behavior alienation-based on theoretical analysis and empirical test of not fully effective market," Collected Essays on Finance and Economics, vol. 3, pp. 79-85, 2010.

[9] R. Q. Fang, "Fair value, irrational psychology and corporate investment efficiency," Journal of Dongbei University of Finance and Economics, vol. 1, pp. 89-96, 2015.

[10] L. Zhang, Q. Farooq, Y. Zhang, X. Liu, and Y. Hao, "Fair value and mispricing: how domestic earnings transparency of listed firms leads to global financial stability," European Journal of International Management, vol. 14, no. 1, pp. 173-193, 2020.

[11] U. Malmendier and G. Tate, "Who makes acquisitions? CEO

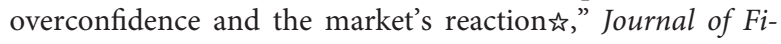
nancial Economics, vol. 89, no. 1, pp. 20-43, 2008.

[12] C.-Y. Lin, Y. Chen, P.-H. Ho, and J.-F. Yen, "CEO overconfidence and bank loan contracting," Journal of Corporate Finance, vol. 64, 2020.

[13] K. Wang, Y. Z. Chen, Y. Liu et al., "Board secretary's financial experience, overconfidence, and SMEs' financing preference: evidence from China's NEEQ market," Journal of Small Business Management, vol. 23, 2020.

[14] H. Shefrin, "Behavioral corporate finance," Journal of Applied Corporate Finance, vol. 14, no. 3, pp. 113-126, 2005.

[15] J. B. Heaton, "Managerial optimism and corporate finance," Financial Management, vol. 31, no. 2, pp. 33-45, 2002.

[16] M. Gombola and D. Marciukaityte, "Managerial overoptimism and the choice between debt and equity financing," Journal of Behavioral Finance, vol. 8, no. 4, pp. 225-235, 2007.

[17] M. G. Yu, X. P. Xia, and Z. S. Zou, "The relationship between managers' overconfidence and enterprises' radical behavior in incurring debtsby," Management World, vol. 8, pp. 104-112, 2006.

[18] C. C. Li, T. C. Zhou, and B. Wan, "Analysis of corporate financing behavior based on the theory of overconfidence," The Impact of Science on Society, vol. 4, pp. 30-34, 2009.

[19] S. H. Penman, "Financial reporting quality: is fair value a plus or a minus?" Accounting and Business Research, vol. 37, no. 1, pp. 33-44, 2007.

[20] D. Aboody, M. E. Barth, and R. Kasznik, "Do firms understate stock option-based compensation expense disclosed under SFAS 123?" Review of Accounting Studies, vol. 11, no. 4, pp. 429-461, 2006.

[21] W. Beaver and M. Venkatachalam, "Differential pricing of components of bank loan fair values," Journal of Accounting, Auditing \& Finance, vol. 18, no. 1, pp. 41-68, 2003.

[22] D. Nissim, "Reliability of banks' fair value disclosure for loans," Review of Quantitative Finance and Accounting, vol. 20, no. 4, pp. 355-384, 2003.

[23] N. P. B. Bollen and V. K. Pool, "Do hedge fund managers misreport returns? Evidence from the pooled distribution," The Journal of Finance, vol. 64, no. 5, pp. 2257-2288, 2009.

[24] J. R. Dietrich, M. S. Harrism, and K. A. Muller, "The reliability of investment property fair value estimate," Journal of Accounting and Economics, vol. 30, no. 2, pp. 125-158, 2000.

[25] D. Herrmann, "The sale of assets to manage earning in Japan," Journal of Accounting Research, vol. 41, no. 3, pp. 89-108, 2003.

[26] X. D. Chi, "Analysis on fair value and earnings managementtaking financial instruments as an example," China Collective Economy, vol. 25, pp. 144-145, 2010. 
[27] M. X. Li, "Discussion on the improvement of financial reporting from the perspective of comprehensive income," Friends of Accounting, vol. 22, pp. 17-21, 2014.

[28] W. P. Yang, "Fair value measurement and earnings management of available-for-sale financial assets-a case study based on fujian nanzhi," Green Finance and Accounting, vol. 6, pp. 11-14, 2015.

[29] M. L. A. Hayward and D. C. Hambrick, "Explaining the premiums paid for large acquisitions: evidence of CEO hubris," Administrative Science Quarterly, vol. 42, no. 1, pp. 103-127, 1997.

[30] F. X. Jiang, M. Zhang, Z. F. Lu et al., "Managerial overconfidence, firm expansion and financial distress," Economic Research Journal, vol. 44, no. 1, pp. 131-143, 2009.

[31] Z. F. Li, H. L. Li, and Y. J. Lian, "The market reaction to the presentation of the changes in the fair value: evidence from Chinese listed firms," Accounting Research, vol. 10, pp. 13-19, 2013.

[32] M. E. Barth and G. Clinch, "Revalued financial, tangible, and intangible assets: associations with share prices and nonmarket-based value estimates," Journal of Accounting Research, vol. 36, pp. 199-233, 1998.

[33] D. Aboody, M. E. Barth, and R. Kasznik, "Revaluations of fixed assets and future firm performance: evidence from the UK," Journal of Accounting and Economics, vol. 26, no. 1-3, pp. 149-178, 1999.

[34] F. X. Jiang and J. C. Huang, "Managerial incentive, debt and firm value," Economic Research Journal, vol. 46, no. 5, pp. 46-60, 2011.

[35] Y. He and D. W. Zhang, "Research on managerial traits, debt financing and firm value," Accounting Research, vol. 8, pp. 65-72, 2015.

[36] H. Xu, Z. G. Lin, and X. Wang, "Relationship-based Transaction,Internal control and earnings management: empirical evidence from accrual and real earnings management," Accounting and Economics Research, vol. 29, no. 3, pp. 57-77, 2015.

[37] K. Zhu, Q. Li, and J. F. Pan, "Incremental value relevance of fair value disclosure under information asymmetry: empirical evidences from China stock markets," Journal of Finance and Economics, vol. 7, pp. 133-143, 2008.

[38] J.-B. Liu, J. Zhao, and Z.-Q. Cai, "On the generalized adjacency, laplacian and signless laplacian spectra of the weighted edge corona networks," Physica A: Statistical Mechanics and Its Applications, vol. 540, 2020.

[39] J.-B. Liu, X.-F. Pan, F.-T. Hu, and F.-F. Hu, "Asymptotic laplacian-energy-like invariant of lattices," Applied Mathematics and Computation, vol. 253, pp. 205-214, 2015.

[40] X. P. Zhu, A. Li, and Y. J. Tang, "Environmental uncertainty, internal control and earnings management-based on the comparison of accruals and real earnings management," Finance and Accounting Monthly, vol. 32, pp. 15-20, 2016.

[41] D. Ghosh and L. Olsen, "Environmental uncertainty and managers' use of discretionary accruals," Accounting, Organizations and Society, vol. 34, no. 2, pp. 188-205, 2009.

[42] Y.-H. Lin, S.-Y. Hu, and M.-S. Chen, "Managerial optimism and corporate investment: some empirical evidence from taiwan," Pacific-Basin Finance Journal, vol. 13, no. 5, pp. 523-546, 2005.

[43] W. Jiang, "Chairman personal characteristics, financial preference and corporate investment," Economic Management, vol. 33, no. 2, pp. 78-85, 2011.

[44] M. G. Yu, W. G. Li, and H. B. Pan, "Managers' overconfidence and Enterprise risk-taking," Journal of Financial Research, vol. 1, pp. 149-163, 2013. 